\title{
Regional development trends in West Bohemia with a special focus on peripheral areas
}

\author{
Martin Kebza ${ }^{1, *}$, Camilla Do Carmo Perotto ${ }^{2}$ \\ ${ }^{1}$ University of West Bohemia, Faculty of Economics, Department of Geography, Czechia \\ 2 University of São Paulo, São Carlos School of Engineering, Brasil \\ * Corresponding author: kebza@kge.zcu.cz
}

\begin{abstract}
In this article, we study regional development trends in the Czech region of West Bohemia through the application of the core-periphery concept. In particular, we focus on the peripheral areas of West Bohemia, the development and differences between its core and periphery, and on the processes of peripheralization. We have used both 'scalar' and 'vector' indicators in the hierarchical cluster analysis. It revealed selective convergent and divergent trends of the core and periphery, in which the peripheralization takes place through the geographic expansion of existing peripheries rather than through the emergence of new isolated peripheries.
\end{abstract}

\section{KEYWORDS}

West Bohemia; periphery; core-periphery axis; regional development; cluster analysis

Received: 19 May 2019

Accepted: 18 August 2020

Published online: 27 October 2020

Kebza, M., Do Carmo Perotto, C. (2020): Changes of socio-economic differentiation in West Bohemia: focus on the developmental tendencies of peripheral areas. AUC Geographica 55(2), 243-254 https://doi.org/10.14712/23361980.2020.18

(C) 2020 The Authors. This is an open-access article distributed under the terms of the Creative Commons Attribution License (http://creativecommons.org/licenses/by/4.0). 


\section{Introduction}

In recent years, we have witnessed the rapid development of national economies, but also crises and other social and political changes that also have a spatial dimension. These concerned, for example, market integration, the opening of borders and the (re-)construction of development policies. These factors have been the catalyst for changes in the territory, whether the strengthening of core areas, the development or decline of the periphery, or the emergence of new development poles. To monitor these changes, we chose the territory of West Bohemia.

The studied regions were selected as representatives of the territories that have been significantly and long-term, possibly permanently, influenced by a political decision. After 1945, over 2 million people had to leave the territory of border territory of Bohemia and Moravia inhabited by population of German nationality (Glassheim 2000), Jelinek (1993) and Frommer (2010) mentions an estimation of 2.5-2.6 million of relocated people. West Bohemia necessarily had a very significant share of Germans due to its geographical location; in a number of border areas, the displaced population of German nationality also constituted a significant ethnic majority. Many villages were completely abandoned and vanished (i.e. Böhmichdorf, Ulrichsgrün, Holzhäuser and many others).

The following period of socialism in this area had several typical aspects - central system, central planning or large-format agriculture; in terms of the settlement system also progressive urbanization and basically no suburbanization. After 1989 there were significant changes that contributed to the transformation of the society. First, the ideological anchoring of state power turned, and the main rules of society's functioning changed with the advent of capitalism. In addition to the society as such, space has also changed. After institutional and social change, territorial followed. The greatest changes in urban and suburban landscapes meant regeneration of urban centres and massive suburbanization (Sýkora, Bouzarovski 2012), which was often noncontrolled. On a wider scale, territorial differences began to widen when forced equalization ended (Hampl 2005). The core role of the largest cities strengthened greatly, and the peripheries had a greater chance to emerge or expand. The transformation period has also taken place in the spirit of strong economic decline and socio-economic disparity in some regions, particularly heavy industry and coal mining base regions.

Such variability occurs also in the territory targeted by this paper. The Plzen Region is associated with the industrial character of the largest city of Plzeň and the transit function (Bavaria-Prague axis). The Karlovy Vary Region is often associated with problems of environmental or socio-economic nature since surface coal mining is widespread and the region is characterized by lower level of education and quality of labour (Hampl 2003).

The goal of this paper is to bring a typology of areas based on socio-economic attributes of the spatial units. The typology should follow the concept of the 'core-periphery' axis. Further, we aim to observe the changes among the types of areas and discuss possible ways of development of West Bohemian peripheral areas, on which this paper focuses the most.

\section{Theoretical background}

Periphery is a designation for specific areas that have a disadvantaged position in terms of social, economic and demographic qualities and are also affected by physical geographic obstacles and barriers in the region (Pociūtè-Sereikienè 2019; Havlíček et al. 2005). Core-periphery axis (see Wallerstein 1979; Friedmann 1966) indicates that peripheries are also, to some extent, determined by the distance from the core on which they depend. Social peripherality can be expressed, for example, in the educational structure and availability of education in general. The age structure of the population captures the demographic peripherality, assuming that the peripheral areas will have a higher proportion of post-productive population compared to the youngest generations (Kebza 2018; Bański 2005), the peripheral character is also captured by negative migration balances (Kubeš, Kraft 2011). Economic peripherality is based on lower economic potential. Industries with high added value are usually not concentrated in peripheries, not even important shopping centers, and jobs may also be unavailable. From the economic point of view, integration into the market system is important. In peripheral areas, however, it is insufficient and results from functional-spatial relationships disorder (Schmidt 1998). If the territory is completely removed from the integration, the term 'margin' is used to describe the non-productive territory affected by total isolation or out of the system (Pileček, Jančák 2011). The deepening of regional differences, or rather of peripheries, is exacerbated by the absence or lack of innovative activities and potential (Kühn 2015). On the other hand, active local entrepreneurs who form the economic base are not fundamentally limited by the peripheral character of the territory and can even benefit from it (Bečicová, Blažek 2015; Felzensztein, Gimmon, Aqueveque 2013).

Recent research also points to differences between the periphery as a static concept and the peripheralization as a dynamic process of changing the qualities of the territory (Kühn 2015; Lang 2012). An important element of the debate is also the knowledge about the possibilities of development of peripheral areas. While Humer (2018) discusses the possible impacts of the 'top-down' strategy of polycentric settlement system development on peripheries (in which the author 
sees some bugs), other authors consider options that require a 'bottom-up' approach of local actors. Human capital of municipal representatives and its effects is dealt by Pileček (2011), while Mayer, Habersetzer and Meili (2016) emphasize local entrepreneurs and their ability to create periphery-core ties in a way that a competitive environment is created in the periphery and the importance of dependence on cores is not that significant. Kebza (2018) put stress on innovation and the 'creative class' in the peripheral areas that could be essential for the future development.

However, peripheries might also be shaped by the perception of local people or the political representation (Willet, Lang 2018), but also by the external world. Such a negative perception is very difficult to overcome, despite considerable efforts.

Although remote positions at state (see Kubeš, Kraft 2011; Havlíček, Chromý 2001) or other administrative borders (Kebza 2018; Musil, Müller 2008) are often common for peripheral areas, these concepts cannot be perceived as identical. Boundaries can contribute to peripherality if they form a (political) barrier, but they cannot determine it. In Europe we find examples of border areas that we could not regard as peripheral (e.g. cities of Copenhagen-Malmö, Lille or Bratislava and their surroundings). In the case of Czechia peripheries often appear in mountainous borders and regional borders (Musil, Müller 2008), which are remote and far from important cores.

Similarly, it is necessary to approach the concepts of periphery and rural. Like some authors reject the understanding of one compact rural area and di-vide it into different groups according to various characteristics (Hedlund 2016), it is not easy to accept the claim of one periphery. Rural areas can be of peripheral nature, however, 'rural' also often includes suburbs of large cities and other rural areas with high development potential, which cannot be described as peripheral. This difference is clearly presented by Perlín, Kučerová and Kučera (2010), who distinguish the category of Moravian peripheries from seven other rural areas in their typology.

Like the rural, the peripheries can be also divided into several types. Kebza (2018), on the example of the West Pomeranian Voivodeship, divides the territory into several categories containing metropolitan (and semi-metropolitan) areas, semiperipheries and four types of peripheries:

- periphery located at the country borderline (in the case of bordering with more countries, it is possible to divide them further as frontiers with different countries can bring different effects),

- bordering periphery, that is situated at the boundary of self-governmening regions, but within the state,

- inner periphery, whose location is not related to any state border nor boundary of self-governing regions,
- pleasure periphery, which is a special category of a seaside or other area with highly developed tourism.

The possible typology of the peripheral areas can also be derived from other characteristics, whether in addition to the location there are attributes based on the dominant aspect of peripherality, peripheriality level (Pociūtè-Sereikienè 2019) or developmental tendencies of the territory.

Our research questions mainly concern the changes in spatial pattern and developmental tendencies affecting peripheries:

- Does the peripheralization process and thus 'production' of peripheries take place in West Bohemia?

- Are the differences between local core and peripheral regions widening?

- How do the dynamics of socio-economic development of peripheral, core and transitional (semi-peripheral) areas differ?

\section{Studied area}

The discussed territory of West Bohemia is composed of two administrative regions (see Fig. 1). Both Plzeň and Karlovy Vary Regions are on NUTS 3 level. Based on the East-West gradient concept, West Bohemia should have a very favourable location and should benefit from the proximity of progressive Bavaria. It turns out, however, that the long-term effects of the Iron Curtain, the displacement of inhabitants, and partly the relief or environmental problems in the Sokolov Basin, constitute barriers to fundamental development throughout the territory. The territory is typical of a large number of vanished municipalities (see Zaniklé obce 2019). According to the analysis of Novák and Netrdová (2011), problematic areas form a significant part of the region, mainly territories distant to larger towns (areas between Strakonice and Sušice, Stř́ibro and Horšovský Týn) and the north-eastern border of the studied region. On the contrary, larger cities and their surrounding areas, like Klatovy, Domažlice, Cheb, Karlovy Vary and especially Plzeň with its wider area and a significantly extended axis in the direction of Prague can be counted among the potential growth poles. Plzeň, as the second most populated city of Bohemia, is closely connected with Prague; the railway corridor and the motorway complement the system of medium-sized cities with a significant number of jobs in commercial premises (e.g. Rokycany, Žebrák or Beroun). Although very important transport routes pass through the area (see Fig. 1), the density of transport networks is described as weak (Drahošová 2011).

The development of the territory is also limited from several directions, especially in terms of human capital (Hampl 2003). Areas around Tachov and Cheb have below-average values of the educational 


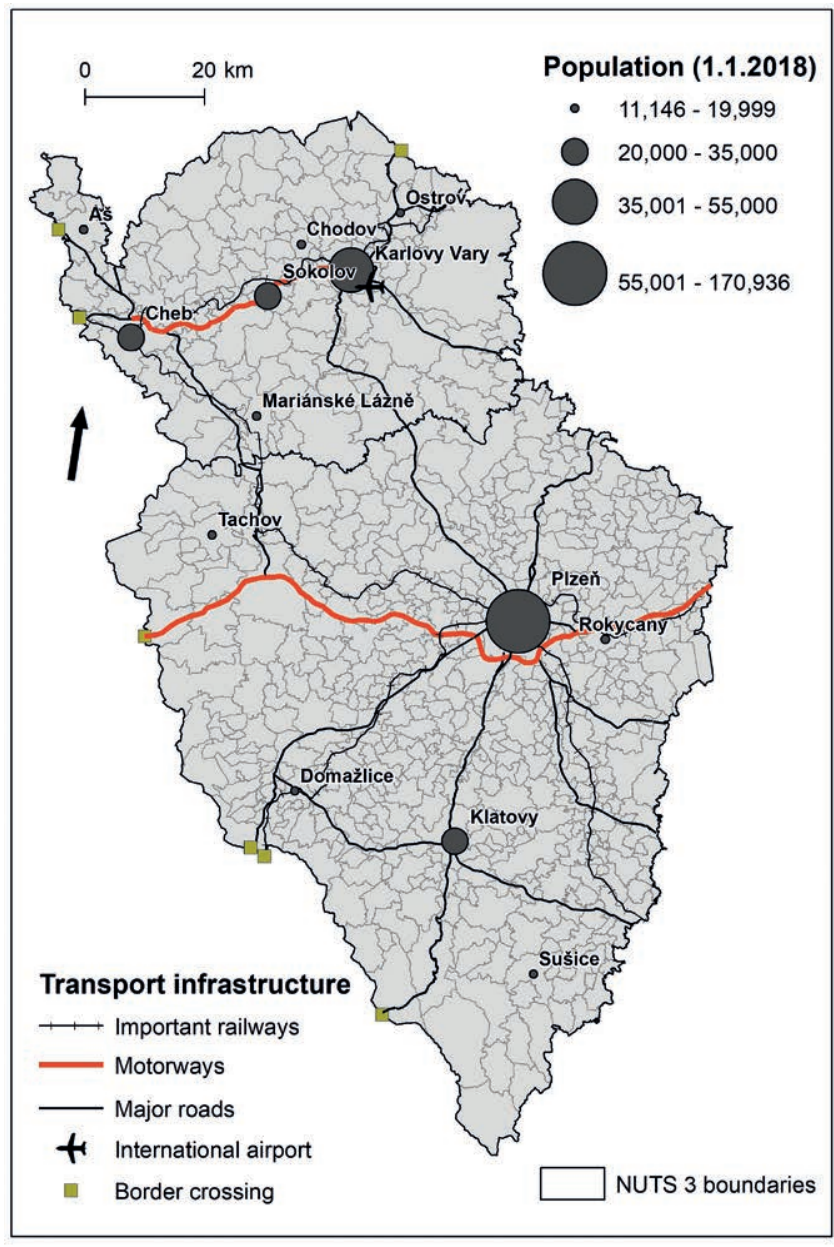

Fig. 1. Biggest cities and towns in Plzeň and Karlovy Vary Regions by population.

Source of data: Čsú (2019)

structure of population (Hübelová 2014). Novotná, Šlehoferová and Matušková (2016) introduce a number of other contrasts, where Plzeň and its surroundings are significantly different from the distant parts of the region.

\section{Methods}

If we want to study the peripheries in a particular area, spatial delimitation of them is necessary. However, the study of peripheries cannot be isolated (Havlíček, Chromý 2001). Thus, it is also naturally needed to demarcate the core and the transition zone formed by semiperipheries, which are socio-economically more advanced and more integrated than the peripheries (Wallerstein 1979).

The methods described below reflect the aim of the paper, especially to identify peripheral areas in West Bohemia on the basis of the above-discussed aspects of peripherality and to monitor the development trends of these areas in comparison mainly with the core areas.

For the purposes of this research, the years 2007 and 2017 were selected for comparison. In 2007, integration into European structures even at institutional level was already under way, while the initial wave of radical spatial changes, such as massive and uncontrolled suburbanization, that emerged under the third phase of transformation (Sýkora, Bouzarovski 2012) was ending. A decade later, these processes may appear in advanced form, probably closer to the natural trajectory. It would certainly be enriching to add this file to 1997, but this does not allow the limits of the data base.

The selection of suitable spatial units that enter the analysis is important. In general, relatively large number of empirical works are devoted to analyses at regional level (NUTS 2, NUTS 3 or similar). The evaluation of these units affects the regions as a complex territory based on functional relations, but the reduction of internal differences somewhat generalizes. Basic administrative units have been used for similar research (Kebza 2018; Novák, Netrdová 2011; Blažek, Netrdová 2009; Džupinová et al. 2008) as well as authors' non-standard units (Novotná, Šlehoferová, Matušková 2016; Musil, Müller 2008). These units are used for a more detailed insight into proposed geographical reality. A disadvantage, however, may be that the expression of extreme values is easier; the smallest municipal population in the area - Čilá had only 16 inhabitants (ČSÚ 2019) in December 31, 2017 and belongs to the smallest municipalities in whole Czechia; in West Bohemia there are another 60 municipalities (out of 635) with less than 100 inhabitants, and only one of these is located in the Karlovy Vary Region (Přebuz, the smallest official Czech town). In this respect, partial distortions (outliers) can be expected, and must be taken into account in the interpretation.

For the statistical analysis, 4 scalar and 2 vector indicators were chosen. The selection should correspond to social, economic and demographic aspects of peripheriality mentioned in the theoretical part of the article. Scalar indicators are tied to the socio-economic characteristics of a given territory, while vector ones consider the distance to the municipality with certain central functions. Scalar indicators have a numerical superiority to avoid fogging or overlapping some of the potential phenomena that could occur near to major cities.

Tab. 1 Scalar and vector indicators used in the analysis and their presupposed values in relation to the typology.

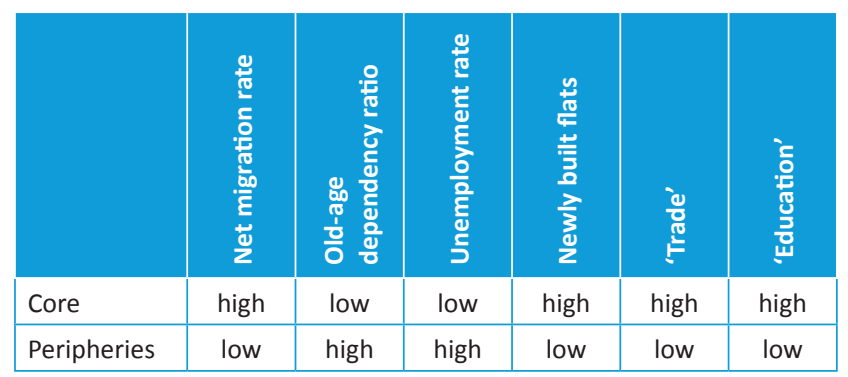

Source: authors' elaboration 
Four scalar indicators are selected to respect the elements of peripherality mentioned above - population stability (net migration rate) and age structure of population (old-age dependency ratio). We monitor the economic potential by the unemployment rate, although it also has a social overlap (Nováček 2014). From the point of view of population stability we also express the attractiveness of the area by housing construction in municipalities (newly built flats per capita).

Net migration rate and newly built flats were measured for 2002-07 and 2012-17 since data for only one year could bring significant distortion. Both indicators mainly reflect the residential attractiveness of the area.Low or negative migration can positively correlate with high unemployment rate and create 'futureless localities'. The social aspect of peripherality is expressed by old-age dependency ratio, as the older population is typical for peripheral areas (Bański 2005).

Vector indicators, here called 'Trade' and 'Education' by nature take into account the distance (geometric peripherality), specifically retail and tertiary education centres. Quantities are calculated similarly to the contribution of Kebza (2018), a detailed methodology is described below. Retail centre is a city with a large-format, despecialized shopping mall with a relevant gross leasable area (GLA). Such cities or municipalities are usually important points of the settlement system, which have a large catchment area; in the case of more developed agglomeration, these shopping malls can also be located in the hinterlands of the centre as an element of commercial suburbanization. The centre of education is a city with a public university. These institutions have very wide catchment areas as public universities in the Czechia are concentrated in a relatively small number of large cities.

Due to the use of vector indicators, our own methodology approaches a variation on gravity models. This concept was used in the past (Wang, Guldmann 1996; Ogden 1978; Reilly 1931). This concept is also currently represented in academic work (Kraft, Blažek 2012). As Frantál et al. (2016) state in the title of their contribution, distance matters.

In addition to the above-mentioned indicators, other ones are used in similar empirical works. Data of those are often only available for larger territorial units. A good example of an economic indicator is the economic aggregate (described in Dostál, Hampl 2008; Hampl 2005), which includes the average monthly wage, that was used also as a single indicator, e.g. in works of Kubeš and Kebza (2018), Skaličková (2015), or Marada (2001). The other indicators among others include the share of university educated population, sectoral employment, share of commuters or development of technical infrastructure (see Kubeš, Kebza 2018; Novotná, Šlehoferová, Matušková 2016; Huggins, Thompson 2014; Czapiewski 2005; Quadrado et al. 2001 and others).
The vast majority of these indicators are 'scalar', statistical data primarily related to the internal characteristics of the territory without taking into account external relations. A specific feature of this paper is the use of vector indicators that emphasize the dependence of (peripheral) territory on core or central areas (see Pileček, Jančák 2011). The use of vector indicators was inspired mainly by the publication of Džupinová et al. (2008), but they were also used in other contributions for the delimitation of peripheries. Kubeš and Kraft (2011), in this sense, use the time accessibility of municipalities to important centres as the only indicator of the delimitation of peripheries.

Here, a modified method of Kebza (2018) is used: vector indicators were calculated using the coefficient of the centre's range $\left(\mathrm{k}_{1}\right)$, the coefficient of the centre's power $\left(\mathrm{k}_{2}\right)$ and the composite coefficient $\left(\mathrm{k}_{\mathrm{c}}\right)$. The coefficient of the centre's range was defined differently for both indicators. While at retail centres the presence of shopping malls (to the detriment of size, see the formula below) is of primary importance, the importance of the educational institution corresponds to the number of students, in which the system of financing of universities is based in Czechia. It must be said that other Czech cities, which are not located in West Bohemia, but at least partly influence them, came into the analysis.

$$
\begin{aligned}
& k 1=1.5+\ln (6) \frac{n}{10,000}\left(n=\mathrm{GLA} \text { in } \mathrm{m}^{2}\right) \\
& k 1=\frac{n}{200}(n=\text { number of students }) \\
& k 2=\frac{k 1}{d}(d=\text { distance from the centre }) \\
& k c=\Sigma(\ln k 1) \times m \\
& \left(m=k_{2} \text { for each considered municipality }\right)
\end{aligned}
$$

In order to calculate the $\mathrm{k}_{2}$ coefficients, the distance (by road) from each municipality to each centre of trade or education had to be measured. To optimize the distance measurement, a code powered by Google Maps was done using the Distance Matrix and Geocoding APIs. Developed as a IPython Notebook (also known as Jupyter Notebook), the code provided the distances considering the main routes between the places set by an input file, which contains only the names of the cities.

The values of scalar and vector indicators are analysed together in order to classify the territory and thus to delimitate the peripheral areas. For this purpose, the hierarchical cluster analysis (described e.g. by Kronthaler 2005) is applied for 2007 and 2017 (thus twice). Cluster analysis was performed using the SPSS software. The Ward method was chosen because it usually creates compact, even-sized clusters (Szmrecsanyi 2012) and was used together with the block intervals and standardization between values $0-1$. We assume division into at least 4 categories - cores and their hinterlands (together as central areas), 
semiperipheries (as a transition zones between cores and peripheries) and peripheries. These results from 2007 and 2017 are compared, or more precisely the shift between categories is compared, in terms of shift up (periphery to semiperiphery; semiperiphery to central areas) or down (central areas to semiperiphery; semiperiphery to periphery) in this hierarchy. It is this comparison that can reveal peripheralization in the sense of the expansion or emergence of new peripheries. Furthermore, the values of individual indicators are compared in order to monitor the deepening or reduction of differences, especially between central areas and peripheries, and to monitor developmental tendencies in individual categories.

\section{Results}

After a pilot testing, a total of 5 clusters, which significantly differed in their properties, are distinguished: (i) the area with the most favourable values in all respects around Plzeň and Rokycany was evaluated as core, (ii) medium distant areas with various but average values (iii) rather remote municipalities with favourable unemployment rates and high migration rates, (iv) unattractive areas with high unemployment rates and a negative migration balance $(\mathrm{v})$ remote municipalities with relatively higher unemployment, and almost zero migration increments.

Based on these clusters' properties, the municipalities were divided into three types which follow the concept of 'core-semiperiphery-periphery' axis - the Central area (cluster i), semi-peripheries (ii + iii) and peripheries (iv $+v)$. The resulting typology (Fig. 2) also reflected the shift between the categories between 2007 and 2017 (see Tab. 2), and thus possible integration or disintegration within the given hierarchy.

According to the results of the analysis, the area of West Bohemia can be divided on the basis of the concept of 'core-semiperiphery-periphery' axis. Rather

Tab. 2 Explanation of the typology based on shifts between the classifications.

\begin{tabular}{|l|l|l|}
\hline Category of area & $\begin{array}{l}\text { Classification } \\
\text { in } \mathbf{2 0 0 7}\end{array}$ & $\begin{array}{l}\text { Classification } \\
\text { in } 2017\end{array}$ \\
\hline Central areas & Central areas & Central areas \\
\hline $\begin{array}{l}\text { Disintegrated } \\
\text { central areas }\end{array}$ & Central areas & Semiperipheries \\
\hline Semiperipheries & Semiperipheries & Semiperipheries \\
\hline $\begin{array}{l}\text { Disintegrated } \\
\text { semiperipheries }\end{array}$ & Semiperipheries & Peripheries \\
\hline $\begin{array}{l}\text { Successfully } \\
\text { integrated peripheries }\end{array}$ & Peripheries & Central areas \\
\hline Integrated peripheries & Peripheries & Semiperipheries \\
\hline Peripheries & Peripheries & Peripheries \\
\hline
\end{tabular}

Source: authors' suggestion surprisingly, the whole territory adopts a monocentric image, although there are two administrative regional centres. Such result confirms the dominance of Plzen and its surroundings, that are labelled as the Central area in the typology. Although Karlovy Vary Region has two relatively strong regional centres (Karlovy Vary and Cheb), it lacks the dominant growth pole, which also contributes to poor links with other progressive areas, institutional anchoring, e.g. in the form of a public college (so far, the only one is the Faculty of Economics at the University of West Bohemia with a marginal number of students) or stigma of distant and structurally affected areas.

On the other hand, Plzeň undoubtedly benefits from the position among important supra-regional centres, which gained in importance Czechia joined the Schengen area in 2007. Prague, Plzeň and Nuremberg create an important axis in Czechia recognized by the Ministry of Regional Development (2015) as a development axis. The stability of the Central area is also supported by the internal processes that take place in the urban agglomeration of Plzeň: ongoing suburbanization and intensifying commuting contribute to the strengthening of ties and thus stronger integration of the municipalities around Plzeň. The

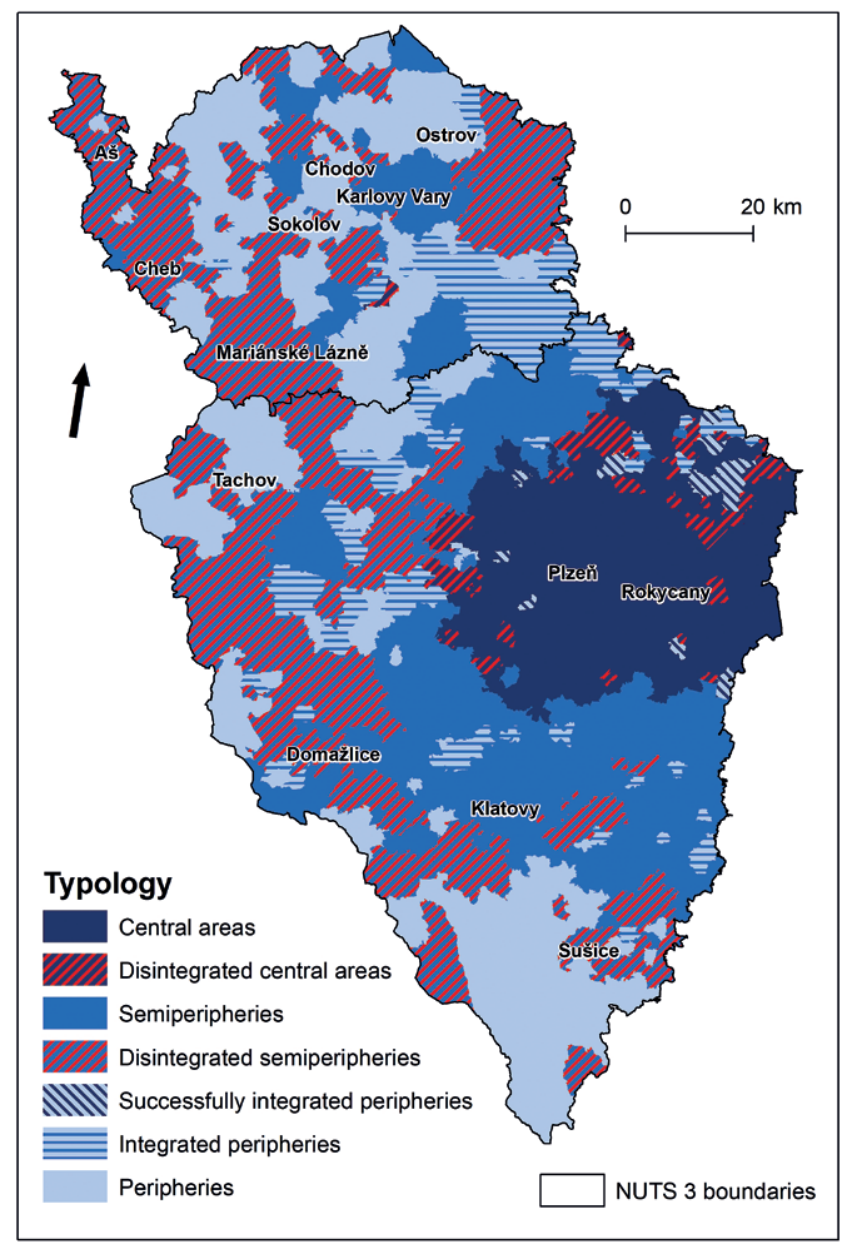

Fig. 2. Typology of areas according to the cluster analysis. Source: authors' elaboration 
Tab. 3 Basic characteristics and average values of indicators according to the typology, year 2007.

\begin{tabular}{|c|c|c|c|c|c|c|c|c|}
\hline $\begin{array}{l}\text { Category } \\
\text { of area }\end{array}$ & $\begin{array}{l}\text { Area } \\
\left(\mathrm{km}^{2}\right)\end{array}$ & $\begin{array}{l}\text { Population } \\
\text { (thousands) }\end{array}$ & $\begin{array}{c}\text { Unemployment } \\
\text { rate }(\%)\end{array}$ & $\begin{array}{l}\text { Net } \\
\text { migration } \\
\text { rate (\%) }\end{array}$ & $\begin{array}{c}\text { Old-age } \\
\text { dependency } \\
\text { ratio (\%) }\end{array}$ & $\begin{array}{l}\text { Newly built } \\
\text { flats per } 100 \\
\text { inhabitants }\end{array}$ & $\begin{array}{c}\text { 'Trade' } \\
\left(\mathbf{k}_{\mathrm{s}}\right)\end{array}$ & $\begin{array}{l}\text { 'Education' } \\
\left(k_{s}\right)\end{array}$ \\
\hline Central areas & $1,655.8$ & 299.9 & 2.6 & 8.8 & 21.4 & 2.7 & 11.2 & 51.6 \\
\hline $\begin{array}{l}\text { Disintegrated } \\
\text { central areas }\end{array}$ & 279.0 & 9.7 & 3.1 & 11.3 & 29.1 & 4.0 & 8.4 & 44.0 \\
\hline Semiperipheries & $2,490.5$ & 158.2 & 3.4 & 5.7 & 24.1 & 1.7 & 4.5 & 32.6 \\
\hline $\begin{array}{l}\text { Disintegrated } \\
\text { semiperipheries }\end{array}$ & $3,013.2$ & 209.1 & 4.2 & 6.3 & 18.1 & 2.1 & 1.2 & 23.7 \\
\hline $\begin{array}{l}\text { Successfully } \\
\text { integrated } \\
\text { peripheries }\end{array}$ & 96.1 & 2.1 & 7.9 & -3.1 & 22.9 & 1.3 & 9.4 & 47.3 \\
\hline $\begin{array}{l}\text { Integrated } \\
\text { peripheries }\end{array}$ & 864.3 & 18.8 & 8.0 & -0.6 & 22.2 & 1.0 & 4.9 & 34.7 \\
\hline Peripheries & $2,560.0$ & 156.2 & 7.7 & 0.9 & 17.8 & 1.5 & 0.8 & 23.3 \\
\hline
\end{tabular}

Source: ČSú (2019), authors' calculations

significant dynamics of Plzeň compared to the rest of the region also reflects the innovation potential (Dokoupil, Preis, Novotná 2016).

The compact Central area is followed by a group of municipalities that do not hold the growth rate and are labelled as 'disintegrated central areas', although strong ties with the city of Plzen may persist. It is a small group of 27 municipalities, for which the unemployment rate has risen on average and the old-age dependency ratio has risen sharply (see Tables 3 and 4). 'Outer ring' of the Central area is complemented by 'successfully integrated peripheries'. Those areas were of peripheral nature in 2007, but in 2017 already belongs to the Central area. This interesting sample of only 12 municipalities apparently underwent successful integration into the most progressive part of the region, when they managed to reduce the unemployment rate by more than half during the period under review, the migration balance changed completely and housing construction also increased; at the same time, an increase of dependence on Pilsen can be expected.

The following group of municipalities are semiperipheries. These are increasingly typical of the Plzeň Region, where they form two larger compact territorial units to the south and north of the Central area. Very selectively, semiperipheral municipalities appear in the Karlovy Vary region, especially in its eastern (inland) part. Some larger cities such as Karlovy Vary or Klatovy belong among the semi-peripheral municipalities. More distant semiperipheral communes can be considered as places of amenity migration. However, there is also a large number of municipalities that were evaluated as semiperipheral in 2007 and their attractiveness in terms of migration and housing construction has changed negatively ('disintegrated semiperipheries'). Many of these municipalities are near the border and are more distant, but there are also

Tab. 4 Basic characteristics and average values of indicators according to the typology, year 2017.

\begin{tabular}{|c|c|c|c|c|c|c|c|}
\hline Category of area & $\begin{array}{l}\text { Population } \\
\text { (thousands) }\end{array}$ & $\begin{array}{c}\text { Unemployment } \\
\text { rate (\%) }\end{array}$ & $\begin{array}{l}\text { Net migration } \\
\text { rate (\%) }\end{array}$ & $\begin{array}{c}\text { Old-age } \\
\text { dependency } \\
\text { ratio (\%) }\end{array}$ & $\begin{array}{l}\text { Newly built } \\
\text { flats per } 100 \\
\text { inhabitants }\end{array}$ & $\begin{array}{c}\text { 'Trade' } \\
\left(\mathbf{k}_{s}\right)\end{array}$ & $\begin{array}{l}\text { 'Education' } \\
\left(\mathbf{k}_{\mathrm{s}}\right)\end{array}$ \\
\hline Central areas & 318.0 & 2.2 & 5.3 & 28.4 & 2.5 & 13.0 & 48.7 \\
\hline $\begin{array}{l}\text { Disintegrated } \\
\text { central areas }\end{array}$ & 9.9 & 4.3 & 3.4 & 42.6 & 2.9 & 10.2 & 41.7 \\
\hline Semiperipheries & 159.9 & 2.6 & 6.0 & 32.0 & 1.6 & 6.8 & 30.9 \\
\hline $\begin{array}{l}\text { Disintegrated } \\
\text { semiperipheries }\end{array}$ & 203.7 & 3.1 & -0.7 & 27.9 & 1.3 & 4.3 & 22.5 \\
\hline $\begin{array}{l}\text { Successfully } \\
\text { integrated } \\
\text { peripheries }\end{array}$ & 2.4 & 3.2 & 6.6 & 28.6 & 1.5 & 11.3 & 44.8 \\
\hline $\begin{array}{l}\text { Integrated } \\
\text { peripheries }\end{array}$ & 18.7 & 4.9 & 5.1 & 33.0 & 1.3 & 7.4 & 32.9 \\
\hline Peripheries & 149.5 & 4.6 & -2.7 & 26.3 & 1.2 & 4.7 & 22.3 \\
\hline
\end{tabular}

Source: ČSú (2019), authors' calculations 
relatively large cities such as Cheb or smaller regional centres Aš, Domažlice, Mariánské Lázně and Sušice within this category.

Furthermore, a large group of rather smaller municipalities in the northern part of the Plzen Region and the south-eastern part of the Karlovy Vary Region is demarcated, with an increase of net migration rate and the number of newly built flats, as well as a decrease in the unemployment rate. This group is called 'integrated peripheries', although it is not only about economic integration. However, the shift in socio-economic characteristics compared to the 'successfully integrated peripheries', which are much closer to Plzeň, is weaker.

Finally, a large number of municipalities form a peripheral area. West Bohemian peripheries are mainly composed of remote hilly and mountainous areas in the southern part of the Plzen region, some of the border areas and various parts of the Karlovy Vary region. These peripheries maintain relatively high unemployment and migration decline, thus slightly moving away from other groups of municipalities. At the same time, the peripheralization in terms of the production of new peripheries, or rather their expansion, can be noticed. The newly peripheral areas ('disintegrated semiperipheries') are spatially connected to the existing peripheries and, with the exception of near Klatovy, no new compact peripherals are created.

Simultaneously, similarities with the terms of 'borderland' and 'rural' are shown - while peripheral areas to some extent correspond to the state (but rather not regional) border, rural areas form only a part of the peripheries. The verification calculation of the urbanization (share of population living in cities and towns over 3,000 inhabitants) showed that semiperipheries are significantly rural and the peripheries are, on the contrary, urbanized the most (64.4\%) right after the central area (72.4\%). Peripheral character of several large cities (Sokolov, Ostrov, Chodov, Tachov) contributes to the degree of urbanization.

According to the achieved results, even these peripheral areas cannot be compared with marginal areas, which are completely outside the integration processes, and thus 'outside the system'. In this case, it is possible to discuss the connection of peripheral areas by public transport to local centres, which operates throughout the territory (Podlešáková 2019), but locally there may be a danger of excessive dependence on one or a few roads (Šumava, Ore Mountains, Český les, Aš promontory).

As the results show, Karlovy Vary Region needs some special attention. Nowadays, Karlovy Vary Region is mostly covered by peripheral areas which are tightly characterized by high unemployment rates and low or even negative values of net migration rate. The depopulation, in addition to the previous analysis, can be related to regional economic development during the socialist era, when coal mines and heavy industries (especially in Sokolov district) expanded in the region to make Czechoslovakia a 'forge of the socialist camp' (Frantál, Nováková 2014). According to Dostál and Hampl (2002), low levels of qualification and flexibility of labour also worsen the context of Karlovy Vary Region. The vulnerability of Karlovy Vary Region is currently attested by the lowest employment rates in agriculture (Věžník, Bartošová 2012) and lower growth rates of gross fixed capital (Rusiński, Pietrusiak 2017). There is a multidimensional debate on convergent or divergent tendencies between defined types of territory. All of them are largely influenced by a broader context covering (inter)national trends and issues. Considering the indicators used, in some cases the semiperiphery approaches the Central area and the peripheries take on a completely different trajectory (net migration rate), in others the peripheries approach the other groups (unemployment, 'Trade') and in other cases there is neither convergence nor divergence (newly built flats, old-age dependency ratio, 'Education').

Looking in detail at the individual indicators, we find that the highest values of old-age dependency ratio are at the eastern border of the Plzen Region. The peculiarity of this territory is the relatively 'younger' population in the borderlands, which has its historical-geographical causality. Dufek and Minařík (2009) believe that policies designed for migration flows can reduce the changes caused by the process of ageing of the population. Net migration rates for 2002-2007 and 2012-2017 periods were measured and then showed a complex scenario for demographic development, in which patterns and significant positive migration flows were predominantly found in urban agglomeration of Plzeň. Mountain and hilly areas that lack adequate infrastructure, education or job opportunities are most depopulated. However, some of these areas, which are aesthetically attractive (Šumava), are undergoing the construction of a relatively higher number of flats that are intended for second homes (recreation).

The unemployment rate followed the state of the national economy and decreased significantly in the period under review. Even so, it is possible to observe significant differences between Plzeň, its surroundings and the problematic area around the towns of Tachov, Sokolov or Sušice, or the entire northern border of the Plzeň Region. In general, the smallest changes are shown in the share of agricultural and forest land. It had decreasing tendency mainly in the suburban area of Plzeň, which we have expected (see Tab. 1).

Vector indicators represent dependence on cores. Several cities (Plzeň, Karlovy Vary, Prague, Cheb, Ústí nad Labem, České Budějovice, Most, Teplice, Chomutov, Př́bram, Strakonice, Rakovník, Beroun and Králův Dvůr) were considered for testing the calculation of the $k_{1}$ and $k_{2}$ coefficients of the 'Trade' and 'Education'. From those cities, only Plzeň, Karlovy Vary, Cheb and Prague for 'Trade' and Plzeň, České Budějovice and Prague for 'Education' were relevant (measurable). 
While the values of 'Trade' have increased in the direction from Prague, Plzeň and Karlovy Vary due to the construction of new shopping centres. 'Education' shows a generally declining trend due to the drop of students, although it is still the strongest in the only university city in the region, Plzeň, and on the axis connecting Plzeň with Prague.

\section{Discussion}

Each of the defined types of territory faces distinct challenges. For example, the Central areas are struggling with socio-spatial changes typical for urban agglomerations - mainly suburbanization that has an impact on the morphological, social and demographic structure of the hinterlands of large cities. Large cities themselves often face gentrification, social segregation, but also environmental challenges and other phenomena.

Development issues, whether of a regulatory or generative nature, are a particularly sensitive topic for transition groups of municipalities, especially for 'successfully integrated peripheries', where the demand for housing and housing has changed.

Quite differently, there are peripheries, which need a developmental impulse instead of regulations. These can be of two types, namely 'top-down', i.e. ideally institutional comprehensive solution, which, however, may not always fully meet the needs of a given territory, and 'bottom-up', when peripheral areas begin to prosper endogenously.

The 'top-down' approach in this regard is the polycentric development approach discussed by Humer (2018). Applied to West Bohemia, a similar development is taking place at a higher hierarchical level (Prague-Plzeň axis). The continuation of this axis towards Bavaria is also expected. Several large industrial zones (e.g. Nová Hospoda) have been opened thanks to the entry into the Schengen area and the completion of the motorway. Contribution of those industrial zones is not unequivocally positive; usually it is a simple production with lack of research and development. The influx of agency workers from abroad can also provoke local social conflicts. Other towns - Cheb, Domažlice or Mariánské Lázně - also have a chance to use the connections with cores through important railways. However, all three cities belong to the 'disintegrated semiperipheries' type, which does not indicate the suitability of this strategy. Such polycentric development strategy would also affect only a few selected areas, and especially more remote peripheries could be left out. The Cheb-Karlovy Vary basin axis has potential in this direction, although it is a short and isolated axis.

We consider the issue of human capital to be essential, both in the form of political and other public representation of municipalities (Pileček 2011) and individuals who are active, creative and willing to stay in their community and develop it. The properties of such a 'creative class' (see Florida 2005) are indispensable for the future development. In this regard, more significant settling of the University of West Bohemia in Cheb would be interesting and potentially beneficial. As a side effect, a deeper anchoring of the university could help to reduce the departure of young people from the peripheral region. A similar direction is represented by Eder (2019), who is exploring knowledge bases in conjunction with peripheries. Thus, the availability of (high-)quality tertiary education seems to be very important from the point of view of human capital development and demographic sustainability. This factor is all the more significant because the West Bohemian peripheries are structurally young (see Tab. 3 and 4) and potentially promising.

Active and creative individuals with the potential for soft development can influence the area through political and other public action, but also through their own business. Local entrepreneurs are dealt by Mayer, Habersetzer and Meili (2016) who look into their ability to create periphery-core ties, the goal should be a competitive environment in the periphery and thus reduced dependence on cores. Start-ups are gaining in economic importance, which also represent a possible way of doing business in the periphery, as demonstrated by Eriksson and Rataj (2019). Moreover, such start-ups can also have a very minimalist form of a municipal workshop with basic equipment.

Karlovy Vary and Plzeň Regions are also known by many square kilometres covered by untouched natural landscapes. While analysing Polish borderlands, Więckowski (2010) evaluates border regions as peripheral areas where there are often cultural, historical and natural attractions, although those features are not enough to develop the whole area itself. The mentioned description matches for Czechia's protected areas, such as Český les and Šumava National Park, and represent a considerable share of land on Bohemian-Bavarian border.

The possibilities of tourism for the purposes of local development are examined by Lang (2012) on the example of Upper Lusatian Hoyerswerda. Its development can have consequences in terms of negative prejudices about the territory and increasing its symbolic attractiveness (Lang 2012). In connection with the development of tourism, however, it must be said that there are places that should preserve the character of remote periphery in the region, those are especially protected natural areas, which are hit by touristification (e.g. Železná Ruda) which leads to decrease of the attractiveness of the locality for tourism, but also for local residents. A strong push for the development of tourism in the amiss perceived peripheries may lead to a 'boomerang effect', when, with institutional support, the perception of locality changes positively, but without subsequent regulation and after touristification, opinion about the place fades again. 
In addition to tourism, peripheries can be a destination for amenity migration, which may also lead to revitalization of settlements (Bartoš et al. 2011). Attractive landscape can attract high-skilled amenity in-migrants which can start deperipheralization processes. This may also apply to the borderland, whose inhabitants were displaced after 1945, which locally becomes a destination for the descendants of former residents who invest financial resources, work and time here.

Finally, peripheral areas can ultimately also benefit from technological progress. A milestone may be the development of high-speed Internet and $5 \mathrm{G}$ networks, which can attract people who only work with computers and do not need social contact, and who do not prefer the urban environment.

\section{Conclusions}

This study presents a discussion on spatial socio-economic differentiation with focus on peripheral areas. The modified methodology of Kebza (2018) based on statistical analysis of basic self-governing units in West Bohemia. The modification of the above-mentioned procedure, which is a variation on gravity models, is based on the typology of territory emphasizing the development and movement of municipalities among the calculated clusters.

The analysis showed that the Central area around Plzeň maintains its position, which is relatively progressive in economic and social terms and also in terms of the availability of retail and tertiary education. The proximity of Plzen is also important for the relatively wide surrounding area. However, the problem is in remote areas and areas with deeper problems and lack of some elements such as universities or employment. Answering the research questions, West Bohemian peripheries do expand, but new significant 'peripheral islets' do not arise. The widening of the gap between peripheries and the Central area is a selective matter, housing construction has remained at a similar level in all types of territory over the years, and unemployment rates even show a slightly convergent trend. The dynamics of socio-economic development in all monitored categories is largely determined by trends in a broader context; from a regional point of view, the consolidation of dominant positions of the core and higher variability in other areas is apparent. Compared to other areas, the periphery stands out from the potential of the younger generation due to the low values of the old-age dependency ratio, which is generally atypical for the periphery. The young(er) population is particularly important, especially in the areas affected by the displacement of population of German nationality. This is a challenge for local participants, who have a chance to take advantage of this state. To do this, it is necessary to strengthen the possibility of self-growth, which includes the availability and quality of education and available opportunities for self-realization.

\section{Acknowledgements}

The research was supported by the Technology Agency of the Czech Republic (TL01000110).

\section{References}

Bański, J. (2005): Suburban and peripheral rural areas in Poland: the balance of development in the transformation period. Geografický časopis 57(2), 117-130.

Bartoš, M., Kušová, D., Těšitel, J., Novotná, M., Kopp, J., Macháček, J., Moss, L. A. G., Gloriso, R. S. (2011): Amenitní migrace do venkovských oblastí České republiky. Kostelec nad Černými lesy, Nakladatelství Lesnická práce.

Bečicová, I., Blažek, J. (2015): Is there a Credit gap in a periphery? The perception of this problem by small entrepreneurs. Journal of Rural Studies 42, 11-20, https://doi.org/10.1016/j.jrurstud.2015.09.006.

Blažek, J., Csank, P. (2005): The West-East gradient and regional development: The case of the Czech Republic. AUC Geographica 35(1-2), 89-108.

Blažek, J., Netrdová, P. (2009): Can development axes be identified by socio-economic variables? The case of Czechia. Geografie - Sborník ČGS 114(4), 245-262, https://doi.org/10.37040/geografie2009114040245.

Czapiewski, K. Ł. (2005): Living conditions and functional structure of rural communes in Poland. Geografický časopis 57(1), 23-42.

ČSÚ (2019): Public database. Praha, ČSÚ - Český statistický úřad.

Dokoupil, J., Preis, J., Novotná, M. (2016): Management inovací v Plzeňském kraji a srovnání se sousedními bavorskými regiony. Trendy v podnikání 6(4), 62-69.

Dostál, P., Hampl, M. (2002): Metropolitan areas in transformation of regional organization in the Czech Republic. AUC Geographica 37(2), 133-155.

Dostál, P., Hampl, M. (2008): Development of national settlement systems in the industrial and post-industrial eras: a general discussion and the case of the Czech Republic. In Strubelt, W., Gorzelak, G. eds. City and Region. Papers in Honour of Jiří Musil. Opladen, BudrichUniPress, 43-54, https://doi.org/10.2307 /j.ctvhktk69.6.

Dufek, J., Minař́k, B. (2009): Age of population and the development of population ageing in the regions of the Czech Republic. Agricultural Economics - Czech 55(6), 259-270, https://doi.org/10.17221/35 /2009-AGRICECON.

Drahošová, J. (2011): Evaluation of transport infrastructure in regions of the Czech Republic. Perner's Contacts 5(6), 58-73.

Džupinová, E., Halás, M., Horňák, M., Hurbánek, P., Káčerová, M., Michniak, D., Ondoš, S., Rochovská, A. (2008): Periférnost' a priestorová polarizácia na území Slovenska. Bratislava, Geografika. 
Eder, J. (2019): Peripheralization and knowledge bases in Austria: towards a new regional typology, European Planning Studies 27(1), 42-67. http://dx.doi.org /10.1080/09654313.2018.1541966

Felzensztein, C., Gimmon, E., Aqueveque, C. (2013): Entrepreneurship at the Periphery: Exploring Framework Conditions in Core and Peripheral Locations. Entrepreneurship Theory and Practice 37(4), 815-835, https://doi.org/10.1111/j.1540-6520.2012.00515.x.

Florida, R. (2005): Cities and Creative Class. New York, Routledge, https://doi.org/10.4324/9780203997673.

Frantál, B., Nováková, E. (2014): A curse of coal? Exploring unintended regional consequences of coal energy in the Czech Republic. Moravian Geographical Reports 22(2), 55-65, http://dx.doi.org/10.2478/mgr-2014-0012.

Frantál, B., Malý, J., Ouředníček, M., Nemeškal, J. (2016): Distance matters. Assessing socioeconomic impacts of the Dukovany nuclear power plant in the Czech Republic: Local perceptions and statistical evidence. Moravian Geographical Reports 24(1), 2-13, http://dx.doi.org /10.1515/mgr-2016-0001.

Friedmann, J. (1966): Regional Development Policy: A Case Study of Venezuela. Cambridge, M.I.T. Press.

Frommer, B. (2010): Národní očista - Retribuce v poválečném Československu. Praha, Academia.

Glassheim, E. (2000): National Mythologies and Ethnic Cleansing: The Expulsion of Czechoslovak Germans in 1945. Central European History 33(4), 463-486, https://doi.org/10.1163/156916100746428.

Hampl, M. (2003): Diferenciace a zvraty regionálního vývoje Karlovarska: unikátní případ nebo obecný vzor? Geografie - Sborník ČGS 108(3), 173-190.

Hampl, M. (2005): Geografická organizace společnosti v České republice: transformační procesy a jejich obecný context. Praha, Univerzita Karlova v Praze.

Havlíček, T., Chromý, P. (2001): Příspěvek k teorii polarizovaného vývoje území se zaměřením na periferní oblasti. Geografie - Sborník ČGS 106(1), 1-10.

Havlíček, T., Chromý, P., Jančák, V., Marada, M. (2005): Vybrané teoreticko-metodologické aspekty a trendy geografického výzkumu periferních oblastí. In Novotná, M. ed. Problémy periferních oblastí. Praha, Faculty of Science, Charles University in Prague, 6-24.

Hedlund, M. (2016): Mapping the Socioeconomic Landscape of Rural Sweden: Towards a Typology of Rural Areas. Regional Studies 50(3), 460-474, https://doi.org /10.1080/00343404.2014.924618.

Hübelová, D. (2014): Regionální disparity kvality lidských zdrojů v České republice v kontextu demografického a ekonomického vývoje. Geographia Cassoviensis 8(1), 34-49.

Huggins, R., Thompson, P. (2015): Culture and Place-Based Development: A Socio-Economic Analysis. Regional Studies 49(1), 130-159, https://doi.org/10.1080 /00343404.2014.889817.

Humer, A. (2018): Linking polycentricity concepts to periphery: implications for an integrative Austrian strategic spatial planning practice. European Planning Studies 26-(4), 635-652, https://doi.org/10.1080 /09654313.2017.1403570.

Jelinek, Y. A. (1993). Violence and Arbitrariness during the Expulsion of Germans from Czechoslovakia: Pages from the Report of the US Liaison Officer. Bohemia 34(1), 123-132.
Kebza, M. (2018): The development of peripheral areas: The case of West Pomeranian Voivodeship, Poland. Moravian Geographical Reports 26(1), 69-81, http:// dx.doi.org/10.2478/mgr-2018-0006.

Kraft, S., Blažek, J. (2012): Spatial interactions and regionalisation of the Vysočina Region using the gravity models. Acta Universitatis Palackianae Olomucensis 43 (2), 65-82.

Kronthaler, F. (2005): Economic capability of East German regions: Results of a cluster analysis. Regional Studies 39(6), 739-750, http://dx.doi. org/10.1080/00343400500213630.

Kubeš, J., Kebza, M. (2018): Geography of socio-economic differentiation of Poland according to subregions in 2002-2014, AUC Geographica 53(1), 36-48. https:// doi.org/10.14712/23361980.2018.4.

Kubeš, J., Kraft, S. (2011): Periferní oblasti jižních Čech a jejich sociálně populační stabilita. Sociologický časopis 47(4), 805-829, https://doi.org/10.13060/00380288 .2011.47.4.08.

Kühn, M. (2015): Peripheralization: Theoretical Concepts Explaining Socio-Spatial Inequalities. European Planning Studies 23(2), 367-378, https://doi.org/10.1080 /09654313.2013.862518.

Lang, T. (2012): Shrinkage, Metropolization and Peripheralization in East Germany. European Planning Studies 20(10), 1747-1754, https://doi.org/10.1080 /09654313.2012.713336.

Marada, M. (2001): Vymezení periferních oblastí a stadium jejich znaků pomocí statistické analýzy. Geografie Sborník ČGS 106(1), 12-25.

Mayer, H., Habersetzer, A., Meili, R. (2016): Rural-Urban Linkages and Sustainable Regional Development: The Role of Entrepreneurs in Linking Peripheries and Centers. Sustainability 8(8), 745, https://doi.org $10.3390 /$ su8080745.

Ministry of regional development of the Czech Republic (2015): Spatial development policy of the Czech Republic: updated version 1. Prague, Brno, Ministry of Regional Development of the Czech Republic, Institute for Spatial Development.

Musil, J., Müller, J. (2008): Vnitřní periferie v České republice jako mechanismus sociální exkluze. Sociologický časopis 44(2), 321-348, https://doi.org /10.13060/00380288.2008.44.2.05.

Nováček, A. (2014): Historical-geographical determinants of the west-east territorialf disparities in the Central European countries. Europa XXI 26, 5-23, https:// doi.org/10.7163/Eu21.2014.26.1.

Novák, J., Netrdová, P. (2011): Prostorové vzorce sociálněekonomické diferenciace obcí v České republice. Sociologický časopis 47(4), 717-744, https://doi.org /10.13060/00380288.2011.47.4.05.

Novotná, M., Šlehoferová, M., Matušková, A. (2016): Evaluation of spatial differentiation in the Plzeň region from a socioeconomic perspective. Bulletin of Geography. Socio-economic Series 34, 73-90, http://dx.doi.org /10.1515/bog-2016-0036.

Ogden, K. W. (1978): The distribution of truck trips and commodity flow in urban areas: A gravity model analysis. Transportation Research 12(2), 131-137, https://doi.org/10.1016/0041-1647(78)90052-7.

Perlín, R., Kučerová, S., Kučera, Z. (2010): Typologie venkovského prostoru Česka. Geografie - Sborník ČGS 
115(2), 161-187, https://doi.org/10.37040 /geografie2010115020161.

Pileček, J. (2011): Potential for the Development of Borderland Peripheries in Czechia in Terms of the Significance of Human Capital: the case of Volarsko. AUC Geographica 46(2), 95-106, https://doi.org /10.14712/23361980.2015.34.

Pileček, J., Jančák, V. (2011): Theoretical and Methodological Aspects of the Identification and Delimitation o f Peripheral Areas. AUC Geographica 46(1), 43-52, https://doi.org/10.14712/23361980.2015 .41.

Pociūtè-Sereikienè, G. (2019): Peripheral regions in Lithuania: the results of uneven development. Regional Studies, Regional Science 6(1), 70-77, http://dx.doi.org /10.1080/21681376.2019.1571437.

Podlešáková, N. (2019): Periferní oblasti Plzeňského kraje vymezení, typy a stabilita. České Budějovice, University of South Bohemia.

Quadrado, L., Heijman, W., Folmer, H. (2001): Multidimensional Analysis of Regional Inequality: The case of Hungary. Social Indicators Research 56(1), 21-42, https://doi.org/10.1023/A:1011893713456.

Reilly, W. (1931): Methods for the Study of Detail Relationships. Bureau of Business Research. Austin, University of Texas.

Rusiński, E., Pietrusiak, D. eds. (2017): Proceedings of the 13th International Scientific Conference, Lecture Notes in Mechanical Engineering. Springer, https:// doi.org/10.1007/978-3-319-50938-9.

Schmidt, M. H. (1998): An Integrated Systematic Approach to Marginal Regions: from definition to development policies. In Jussila, H., Leimgruber, W., Majoral, R. eds. Perception of Marginality: theoretical issues and regional perceptions of marginality in geographical space. Aldershot, Ashgate, 45-66, https://doi.org /10.4324/9780429447457-5.

Skaličková, J. (2015): Differentiation of regions in Czech Republic based on economic indicators. Actual Problems of Economics 8, 245-256.

Sýkora, L., Bouzarovski, S. (2012): Multiple Transformations: Conceptualising the Post-communist Urban Transition. Urban Studies 49(1), 43-60, http:// dx.doi.org/10.1177/0042098010397402.

Szmrecsanyi, B. (2012): Grammatical Variation in British English Dialects: A Study in Corpus-Based Dialectometry. Cambridge University Press.

Věžník, A., Bartošová, L. (2012): Selected regional geographical differences of the Czech Republic agriculture, after the transformation processes. Agricultural Economics (Zemědělská ekonomika) 50, 207-216. https://doi.org/10.17221/5191-AGRICECON. Willet, J., Lang, T. (2018): Peripheralisation: A Politics of Place, Affect, Perception and Representation. Sociologia Ruralis 58(2), 258-275, https://doi.org/10.1111 /soru.12161.

Wallerstein, I. (1979): The Capitalist World-Economy. Cambridge, Cambridge University Press.

Wang, F., Guldmann, J. M. (1996): Simulating Urban Population Density with a Gravity-based Model. SocioEconomic Planning Sciences 30(4), 245-256, https:// doi.org/10.1016/S0038-0121(96)00018-3.

Więckowski, M., (2010): Tourism development in the borderlands of Poland. Geographia Polonica 83(2), 67-81, https://doi.org/10.7163/GPol.2010.2.5.

Zaniklé obce (2019): Města, obce, osady, samoty a další objekty zaniklé či částečně zaniklé (dobové pohlednice, historie, vojenské mapy, místopis) [cit. 2019-01-24]. Retrieved from: http://zanikleobce.cz/index.php ?menu=222?27,108. 